\title{
UVODNIK
}

\section{IZOBRAŽEVANJE IN SKUPNOST}

Sociološko in antropološko je skupno različnim opredelitvam skupnosti - kot pravi C. Fletcher - je to lokalno okolje ljudi, ki imajo interes za skupno ne glede na različnost svojih interesov. Izobraževanje je dražljaj $z a$ in odgovor $n a$ skupnost. Ta odnos je lahko zavesten ali nezaveden, pozitiven ali negativen.

Skupnostno izobraževanje lahko razumemo kot izobraževanje ali učenje $v$ skupnosti ali kot izobraževanje za skupnost. Nas v tej številki Andragoških spoznanj zanima predvsem prvo, to je izobraževanje ali učenje $v$ skupnosti, saj je izobraževanje $z a$ skupnost delovanje izobraževalnih organizacij (šol, izobraževalnih središč itn.) in uporaba njihovih zmogljivosti ter njihovo usklajevanje $\mathrm{z}$ drugimi institucijami in organizacijami (tudi prostovoljskimi) za (izobraževalne) potrebe skupnosti.

Prva različica skupnostnega izobraževanja - izobraževanje $v$ skupnosti - se je krepila in se še krepi v sorazmerju s poudarki, ki jih v družbi dajemo razvoju skupnosti. Večji del izobraževanja in učenja $\mathrm{v}$ skupnosti in tudi sicer je neinstitucionaliziran, je prvina človekove dejavnosti in poteka neformalizirano, neformalno in aformalno. Je stalno prisotno $v$ skupnost $i$ in je pomembna sestavina skupnostnega delovanja. Znani ameriški andragog Roby Kidd je vlogo učenja izrazil s formulo B3, ki jo je treba razumeti kot stopnjevanje treh stanj, to pa so: Being - Becomming - Belonging, v slovenščini: biti - rasti/postajati - pripadati. Formulo si je mogoče poenostavljeno razložiti takole: ne moreš pripadati, ne moreš se socialno vključevati, če ne rasteš, seveda pa si moraš pred tem zagotoviti ustrezno materialno in duhovno eksistenco; vse te dimenzije pomembno določajo učenje kot našo temeljno potrebo in tudi kot sredstvo za naše družbeno vključevanje. Kidd zapiše, da je učenje več kot šolanje, vključuje in obsega vse dejavnosti - od formalnega do aformalnega. V hitro se spreminjajoči družbi sta vzgoja in izobraževanje preveč pomembna, da bi ju prepuščali le učiteljem in šoli. Šola je danes bogata z informacijami, a revna z akcijami; življenje pa terja bogastvo akcij, pravi Torsten Husen v svoji knjigi The Learning Society. Učenje v skupnosti ni novost zdajšnjega časa. Obstaja od nekdaj. Res pa ga zdaj strokovno spoznavamo, prepoznavamo in priznavamo bolj kot v prejšnjih časih. To je posledica razvoja vzgoje in izobraževanja in še posebej izobraževanja odraslih ter sprejetja koncepta vseživljenjskosti učenja. Blizu pojmu »skupnostno učenje« je tudi »vsakodnevno učenje« (everyday learning). Oboje je tesno povezano z življenjem v okolju, v katerem ljudje živijo in delujejo.

Eno najpomembnejših področij sodobnega izobraževanja odraslih je izobraževanje in učenje v prostovoljskih organizacijah. Filozofija takšnega izobraževanja poudarja zlasti 
tele temeljne konceptualne prvine: $\mathrm{v}$ strukturi izobraževanja in učenja prevladujejo neformalno in manj formalizirano izobraževanje ter oblike samostojnega učenja; cilj izobraževanja praviloma ni le ali pretežno posredovanje informacij in/ali znanja članom organizacije, temveč še bolj kot to spodbuditev teh k ustreznemu ravnanju, razvijanju ali spreminjanju navad, stališč, vedenja ipd. ter k razvijanju njihove dejavnosti ali dejavnosti organizacije, ki ji pripadajo; takšne cilje je mogoče dosegati z izobraževanjem ali učenjem, ki aktivno vključuje udeležence in angažira vse razsežnosti njihovega osebnostnega delovanja - intelektualne, čustvene in voljne; izobraževanje in učenje morata biti vsebinsko in izvedbeno načrtovana in izpeljana po meri udeleženca, to je tako, da se upoštevajo njegove potrebe in možnosti, kolikor je mogoče, morata biti prijazna, prijetna in privlačna; metode in oblike izobraževanja, ki to omogočajo, so zlasti delo v majhnih skupinah, delavnice, študijski krožki, projektno delo, razprave, izmenjava izkušenj, ogledi, predstavitve, pa tudi organizirano samostojno učenje, svetovalna pomoč posamezniku itn.; takšno izobraževanje oziroma učenje je v bistvu izkušenjsko učenje in kot takšno daje mnogo bolj trajne učinke kot izobraževanje, ki temelji le na posredovanju informacij in znanja; za izvedbo takšnega izobraževanja so pomembni ustrezno usposobljeni voditelji izobraževanja in učenja (ni nujno, da imajo za to formalno pedagoško usposobljenost), prijetne in spodbujajoče okoliščine za učenje (prostori, učna klima), pripomočki za aktivno učenje, uporaba učne tehnologije itn.

T. Husen v svoji viziji o »učeči se družbi« pravi, da ima »učeča se družba« v vseh prvinah, ravneh in razsežnostih svojega delovanja vgrajeno učenje kot pogonsko silo razvoja. Sestavljajo jo tako posamezniki kot tudi skupine, organizacije in skupnosti. Pomembno za »učečo se družbo« je, da pobuda za učenje prihaja tako od posameznika, ki s tem udejanja svoje »učne projekte«, kot tudi iz družbe (skupnosti, mesta, organizacije, skupine ...), ki se organizira tako, da že s svojim temeljnim delovanjem omogoča učenje in pridobivanje znanja; temu bi lahko rekli tudi »učna klima« (npr. v organizacijah, skupinah) ali »učna kultura« (v družbi). S tem se pomembno obogatijo možnosti izobraževanja in učenja: bolj formaliziranim in razvidnim (šola, izobraževalni programi različnih izvajalcev) se pridružijo tudi manj formalizirane (npr. učenje v skupinah, študijskih krožkih, organizirano samostojno učenje, izmenjava učenja itn.) kot tudi aformalne. Vse to so značilnosti skupnostnega izobraževanja ali izobraževanja v skupnosti. Poleg vertikalne razsežnosti, to je učenja in izobraževanja skozi vse življenje (life-long), človeku (občanu, krajanu) omogočati tudi učenje in izobraževanje $\mathrm{v}$ horizontalni razsežnosti, to je z upoštevanjem vseh mogočih vsebin, vključujoč vso širino življenja (life-wide) v vsakem razvojnem obdobju. Tradicionalna predstava o izobraževanju kot dolžnosti (zahteve poklica in dela) se dopolnjuje tudi z upoštevanjem učenja »za dušo«, veselja za reševanje vsakdanjih problemov, za aktivno državljanstvo in civilno družbo, za človekovo samouresničenje in krepitev njegove samopodobe.

Dober primer »učeče se skupnosti« sem doživel na prireditvi Tedna vseživljenjskega učenja leta 1998 v primorski vasi Knežak. V šolski telovadnici, kjer je potekala prireditev, se je trlo ljudi; vsi, ne le slavnostni govorniki, temveč tudi udeleženci, so govorili o učenju, o 
vlogi in dosežkih učenja v njihovi vasi in širši skupnosti, kaj vse so dosegli z učenjem; to so govorili z vidnim ponosom in veseljem. Poudarjali so obliko učenja, ki jo po vsej Sloveniji uspešno vpeljuje Andragoški center Slovenije (ACS), to je študijski krožek. To, kar so povedali, je kazalo, da jim je z učenjem - začelo se je v študijskem krožku »Uredimo in polepšajmo naš kraj« - uspelo organizirati dejavnosti, ki jih v resnici lahko označimo kot gibanje za revitalizacijo njihovega kraja in širšega okolja. Ker se to dogaja na podeželju in v tistem predelu Slovenije, ki smo ga, morda pa ga še štejemo za ogroženega (upadanje natalitete, izseljevanje, siromašenje življenja in postopno izumiranje), je dosežek še toliko bolj pomemben. Navedeni primer na najbolj prepričljiv način dokazuje, kako je to, kar označujemo kot vseživljenjsko izobraževanje, proces sredi življenja in učenje v najširšem smislu, ki izhaja bodisi iz posameznika bodisi iz družbe. To je zametek »učeče se družbe «, ki se v našem primeru kaže kot »učeča se skupnost « ali vas. To skupnostno učenje v Knežaku s svojo dejavnostjo zagotavlja, da zanjo ni treba toliko ali predvsem skrbeti nekomu od zunaj, saj ljudje sami skrbijo zase in za svoj kraj. Iz skromnih začetkov rastejo njihove nadaljnje zamisli in projekti; iz študijskega krožka raste skupnostno učenje, povezano s skupnostnimi dejavnostmi in novimi oblikami organiziranosti; tedaj so, denimo, ustanovili društvo, ki se imenuje Društvo PIŠKOTEK (prijetno zveneča kratica pomeni: Društvo prijateljev informiranja, športa, kulture, okolja, turizma in ekologije Knežak). Takšni in podobni projekti rastejo iz zamisli in koncepta vseživljenjskosti učenja, kar poskuša promovirati med drugimi projekti tudi Teden vseživljenjskega učenja. To je izjemen prispevek k pospeševanju socialnega vključevanja in njegov neposredni dejavnik. Strokovnjaki za sociologijo izobraževanja sicer trdijo, da izobraževanje samo ne more spremeniti socialnih odnosov in odpraviti socialnih razlik. Tej trditvi lahko na prvi mah pritrdimo, zlasti če mislimo na izobraževanje v njegovi tradicionalni izvedbi; trdno pa sem prepričan, da lahko učenje ali znanje, ki postane sestavina življenja - in to je tisto, kar nam napoveduje strategija vseživljenjskosti učenja - okrepi možnosti našega vplivanja tudi na družbene okoliščine. Dober zgled je bil tudi projekt organizacije Vitra iz Cerknice »Vitra v deželi suhe robe«, ki je bil namenjen revitalizaciji Notranjske; s projektom so želeli tamkajšnja »spalna naselja (Ljubljana čez dan potegne prebivalce iz okolja, kjer bivajo, domov se pretežno vračajo zvečer, utrujeni) revitalizirati s spodbujanjem aktivnosti, za katere pa je bilo treba prebivalce usposobiti (učiti). Toda kot vidimo, $\mathrm{k}$ temu ne daje največjega prispevka sistem formalnega izobraževanja - tako začetnega kot nadaljevalnega - temveč govorimo predvsem o načinih, ki jih vpeljuje celotna strategija vseživljenjskosti učenja in njeno udejanjanje.

Ob prvem Tednu vseživljenjskega učenja (TVU) v letu 1996 smo na letake in lepake pogumno napisali geslo »Slovenija - učeča se dežela«. V njem je bilo seveda precej optimizma in idealizma, zato ga je bilo mogoče razumeti bolj kot željo in cilj, h kateremu smo usmerjeni. Na predstavitvi TVU v letu 2013 pa me je navdušila predstavitev »Parade učenja « $\mathrm{z}$ opisom in video prikazom dogodkov. Tedaj sem v razpravi dejal, da vidim $\mathrm{v}$ tem približevanje udejanjanju gesla, ki smo ga v ACS izbrali ob prvem TVU. Z zadovoljstvom sem ugotavljal, da se izvajalci »Parade učenja « nekaterimi domiselnimi in uspešnimi dejavnostmi temu cilju že kar lepo približujejo. Ta želja se zdaj udejanja že v 
naslovu - prireditve so v podnaslovu projekta organizatorji poimenovali »Dnevi učečih se skupnosti«. Pot k udejanjanju gesla »Slovenija - učeča se dežela« kažejo tudi primeri prikazanih dejavnosti, kot so, denimo, »veriga znanja«, s katero so udeleženci učenja (povezani z rokami v dolgo verigo) pokazali, da se povezujejo v želji po znanju; izraz »gozdna pedagogika«, ki kaže željo udeležencev po učenju neposredno v naravi; odbor za »Parado učenja«, ki so ga ustanovili v eni od skupnosti (na Jesenicah) za zagotavljanje dolgoročnega načrtovanja dejavnosti »Parade učenja «. Opisani primeri - verjetno pa je v vsaki skupnosti kaj izvirnega - nam kažejo nekaj možnosti, kako bi se v Sloveniji z nekaj politične podpore približali postavljenemu cilju, da res postanemo »učeča se dežela«. V majhni državi, kakršna je Slovenija, je to laže doseči kot v velikih, saj je število skupnosti, ki naj bi postale »učeče se skupnosti«, laže obvladljivo kot tam, kjer je število skupnosti zelo veliko.

Vzgojno-izobraževalna politika Slovenije je s svojo sistemsko ureditvijo vzgoje in izobraževanja bolj kot manj formaliziranemu izobraževanju in učenju naklonjena šolskemu in formalnemu, kurikularno zakoličenemu izobraževanju, predvsem otrok in mladine. Izobraževanje v skupnosti, kot ga obravnavamo v tem prispevku, je - podobno kot celotno izobraževanje odraslih - le obrobno področje zanimanja v zdajšnji ureditvi in organiziranosti ministrstva za izobraževanje, znanost in šport; to področje je po organizacijski shemi ministrstva le podpodročje sekcije za višje šolstvo v direktoratu za srednje in višje šolstvo ter izobraževanje odraslih in ni samostojna organizacijska enota (kot so direktorati), kot bi si po svojem pomenu in obsegu zaslužilo. Ker država ne opravlja zadovoljivo svoje vloge, bomo potrebovali močnejši in dovolj odmeven glas »civilne družbe«. Tudi zato, ker so različne plasti naše družbe tozadevno neozaveščene, vklenjene v pojmovni svet in vzorce tradicionalnega šolstva in pouka, ki so rezultat posebno trdožive, nepluralne pedagoško-didaktične in šolske institucionalne kulture in doktrine v Sloveniji. Paradigma učenja, ki jo zastopata filozofija in praksa vseživljenjskega učenja, takšno naravnanost očitno pri nas prej ogroža, kot navdihuje. Zato je na poti preobrazbe izobraževanja (in šolanja) k učenju (kot pravici, sredstvu, veselju in odgovornosti - kot so ga leta 1997 označili na peti Unescovi mednarodni konferenci o izobraževanju odraslih v Hamburgu) pravo zdravilo prav izobraževanje in učenje odraslih. Njegovo vrednost in pomen lahko prej kot »šolsko zasvojena« državna uprava začuti »civilna družba«, to smo vsi, ki danes brez učenja ne moremo več kakovostno ne živeti ne delati. Če naredimo primerjavo: uporabnikov učenja ni nič manj kot porabnikov različnih drugih vrst dobrin (potrošnikov). Slednji pa so kot pripadniki »civilne družbe « mnogo bolje organizirani za zaščito svojih interesov in, če je treba, ofenzivno uveljavljanje svojih pravic. Imajo tudi svojo organizacijo - to je Zveza potrošnikov Slovenije, ki je nedvomno pomemben steber civilne družbe in ima vlogo korektiva državne politike in njenih pomanjkljivosti. Na področju učenja in izobraževanja so uporabniki porazdeljeni po svojih organizacijah (teh je zelo veliko, toliko, kot je različnih ciljnih in interesnih skupin na različnih področjih življenja in dela), to pa je zelo razčlenjena struktura; v njej so tako profesionalne kot tudi druge (ljubiteljske, prostovoljske, nevladne) organizacije, vse pa kot pomemben del svojih programov razvijajo, spodbujajo in organizirajo učenje in izobraževanje svojih pripadnikov; $\mathrm{k}$ temu moramo prišteti še 
vse številnejše izvajalce izobraževanja odraslih, ki se morajo v naših razmerah znajti, kot vedo in znajo. Ta čas pri nas vse te organizacije v družbi še ne nastopajo povezano in organizirano, da bi bodisi zahtevale od države ustrezno politiko učenja in izobraževanja bodisi ponudile državi partnerstvo pri tem. »Civilna družba« na tem področju bo postala organiziran razvojni in politični dejavnik, ko bodo tudi v Sloveniji te organizacije združile svoje moči in vpliv v krovni povezavi za učenje in izobraževanje odraslih. V mnogih (zlasti razvitih) državah takšna združenja že dolgo delujejo (npr. na Švedskem) in so pomemben »civilnodružbeni « partner državi na področju učenja in izobraževanja odraslih, s tem pa pri razvijanju in zagotavljanju posamezniku in družbi potrebnih znanj in veščin ter tega, o čemer naši politiki samo govorijo - »družbe, ki temelji na znanju « in učenju. Takšen razvoj je že sestavni del strategij, ki pod geslom »učenje za vse« (Learning for $A l l)$ nastajajo tako pri Unescu kot tudi pri OECD - dveh ta čas najmočnejših zagovornikih strategije vseživljenjskosti učenja v svetu.

V Sloveniji gotovo bolj pripadamo tistim državam in jezikovnim območjem, kjer je pojem »učenje« izrazito podrejen pojmoma »izobraževanje« in »šolanje«. To je bržkone posledica naše prevladujoče pedagoško-didaktične in šolske institucionalne kulture. Učenec je pri nas otrok; za označevanje odraslega, ki se uči, sploh ne uporabljamo te besede. Povsem drugače je v angleški kulturi in na angleškem govornem območju: »learner« označuje osebo, ki si zna sama organizirati učenje in je praviloma odrasla. Izraz »učenje« vzbuja pri nas nekakšen odpor. V njem delujejo naše neugodne izkušnje iz časa šolanja, kjer je bilo učenje obveznost, prisila, nekaj neprijetnega, nekaj, kar ne prihaja spontano od nas, temveč nam je vsiljeno od zunaj (učitelji, starši, vzgojitelji, šolski urnik itn.); nekaj, za kar smo lahko kaznovani (ne ravno s palico, kot nekoč, ampak s črno piko, »cvekom«, »šponom《 itn., če uporabim nekaj sočnih šolskih izrazov, iz česar sledijo prepovedi in takšne ali drugačne kazni). Z našimi izkušnjami učenja v šoli je redko povezano kaj veselega ali prijetnega. To ni zabava, je resno delo. Ni čudno, da nas ob besedi učenje »strese«.

Tako, žal, dojemamo tudi izraz vseživljenjsko učenje, to pa je v živem nasprotju s tem, kar $\mathrm{v}$ resnici označuje. Za pedagoško prakso je povečini značilno (ne glede na nekatera lepa pedagoška načela), da ne zaupa zmožnosti učenca za avtonomno učenje in vidi možnost učenja (izobraževanja) le v strogo strukturirani in nadzorovani obliki pod vodstvom učitelja, to pa je poučevanje. Na to, da je lahko »učenje« izobraževanju enakovredna ali celo nadrejena dejavnost, so opozorili predvsem andragogika in novejša andragoška spoznanja, ki jih najbolje označuje ugotovitev Alana Thomasa, da je »izobraževanje skupinski in javni odgovor na dejstvo, da se posamezniki učijo«. V gradivu »Vseživljenjsko učenje za vse«, ki ga je objavil OECD, so zapisali, da zaznavamo v zdajšnjem času »paradigmatičen premik od izobraževanja $\mathrm{k}$ učenju « in da do tega prihaja z uveljavljanjem vseživljenjskosti učenja (čeravno se ne moremo strinjati z neoliberalno usmeritvijo, ki jo z dajanjem prednosti ekonomistični vrednosti vseživljenjskega učenja poudarja OECD). Bistvo razlike med izobraževanjem in (vseživljenjskim) učenjem je v premiku od »spreminjajo me« (ali poučujejo me) k »spreminjam se« (učim se). In tudi: »veselim se«, ne le »moram«. Posebno vrednost za uveljavljanje takšnega premika ima prireditev Teden vseživljenjskega 
učenja. Preusmerja nas od negativnih in neprijetnih k pozitivnim pomenom in doživljanju učenja. Utira pot k učenju za nas, za življenje. Učenje v skupnosti pa je pomembno tudi zato, ker daje možnost, da se v najrazličnejših oblikah in na različne načine resnično učijo vsi člani skupnosti, torej tudi tisti, ki so sicer pojmovani kot »nedejavni«, tisti, ki se izobraževanja ne udeležujejo in so torej nekako označeni za »problematične«. Učijo se v društvih, klubih, knjižnicah, dnevnih centrih aktivnosti ali preprosto z druženjem na javnih mestih; gre za vseživljenjsko, problemsko in vsekakor pomembno učenje. Takšno učenje zmanjšuje neenakosti med ljudmi, zmanjšuje družbeno izključenost in vsem članom skupnosti daje možnost za dejavno sooblikovanje družbenega življenja. 